\title{
REFRAMING THE MONGOLS IN 1260: THE ARMENIANS, THE MONGOLS AND THE MAGI
}

ANGUS STEWART ANT

The irruption of the Mongols led to profound changes in the political, cultural and confessional climate of the thirteenth-century Near East. While many did not survive the initial onslaught and the years of turmoil that followed, and rulers that opposed the Mongols were largely swept away, the communities and dynasties that remained were forced to seek some sort of accommodation with the new overlords. While subjection to the Mongol yoke was far from desirable, rulers could seek to make the best of the situation, in the hope that the ambitions of the Mongols might come to match their own, or that the Mongols might be persuaded to support their cause. This paper will consider how certain Christian groups in the Near East sought to reconcile themselves to the Mongol presence, and how they sought to place these alien invaders within a more familiar framework. In particular it will examine the visual evidence for this process by looking at a couple of appearances of recognisably Mongol figures within Christian artwork, dating from the time of the second major Mongol invasion of the region, led by the Ilkhan Hülegü, which by 1260 had extended Mongol power into Syria and to the borders of Egypt. ${ }^{1}$

\section{The Mongol Invasion of Syria}

Hülegü's campaign had, by 1260 , changed the political complexion of Syria drastically. The various ruling Ayyūbid princes had been killed, had fled, or had joined up with the invaders. In addition to these local forces, the Mongol invasion was supported by detachments sent by other local subject princes, including Het'um I, king of the Armenians, and Bohemond VI, prince of Antioch and Tripoli, the northern Frankish states in the Levant.

Since the arrival of the First Crusade, and the formation of the principality of Antioch, the Franks and the Armenians of the region had had close, if not always peaceful, relations. After the foundation at the end of the Twelfth Century of a unified Armenian kingdom based in Cilicia and the surrounding Taurus mountains, the Armenian kings had attempted to dominate the affairs of their Frankish neighbour. By 1260 relations were amicable; Prince Bohemond VI was King Het'um I's son-in-law; and in the previous year Het'um had intervened on behalf of Bohemond in his dispute with the nobles of the county of Tripoli. ${ }^{2}$ It

\footnotetext{
${ }^{1}$ This paper was inspired by a viewing of one of the key images under discussion in the course of a colloquium on "La Méditerranée des Arméniens (XII $-\mathrm{XV}^{\mathrm{e}}$ siècle)", held in the Armenian Patriarchate in Jerusalem in July 2009. I am grateful to the organisers of this colloquium, Gérard Dédéyan and Claude Mutafian, for my invitation. Claude Mutafian and Dickran Kouymjian also offered much kind advice and assistance during the writing of early versions of this piece. Some areas discussed here formed part of papers given at the Universities of Birmingham, St Andrews, Edinburgh and Wisconsin, Madison; I am grateful for the comments and advice given on these occasions, and would like especially to thank Reuven Amitai, Robert Bartlett, Leslie Brubaker, Peter Cowe, Peter Jackson, Susan Manly and David Morgan. I would like to acknowledge my great debt to my colleague Tim Greenwood, whose assistance with the Armenian material has been invaluable.

${ }^{2}$ On this incident see, for example, the Chronicle attributed to Smbat Sparapet, King Het'um's brother, in $L a$ Chronique attribuée au connétable Smbat, translated by Gérard Dédéyan (Paris, 1980), p. 103); see also Sirarpie Der Nersessian, "The Armenian Chronicle of the Constable Smpad or of the 'Royal Historian", Dumbarton Oaks Papers, XIII (1959), p. 160 (a different redaction, here misleadingly summarised). This incident is also
} 
may well be that Armenian influence played a rôle in persuading Bohemond, much to the disgust of his Frankish cousins in Palestine, to enter Hülegü's service. ${ }^{3}$ King Het 'um had accepted Mongol suzerainty himself some years previously. He had learnt of the grisly atrocities inflicted on the Armenian heartlands to the north, as with all touched by Chinggis Khan's great campaign of 1219-21, and by the Mongol army left behind in northern Persia. ${ }^{4}$ When this latter army marched against Anatolia Het'um was quick to seek terms. At the battle of Köse Dagh in 1243, the Mongols defeated the Seljuk Sultan of Rum Kay-Khusraw II, Het'um's probable overlord; by betraying the Sultan's fugitive mother and sister to the Mongols Het 'um was able to buy peace, and obtain Mongol overlordship. ${ }^{5}$ This arrangement was reinforced when Het'um sent his brother the Constable Smbat to the Great Khan, Güyüg, in Qaraqorum. When Güyüg was succeeded by his cousin Möngke in 1251, King Het'um himself set out for the qaghan's ordo, to reconfirm his protected, subject status. He stayed with Möngke for fifty days, and for part of his return journey westward he accompanied the enormous army gathered by the qaghan's brother, Hülegü, on its way to Persia, Iraq and Syria. This army sacked Baghdad in 1258 and subsequently the last caliph himself was killed, ending the ${ }^{\mathrm{c}}$ Abbāsid Caliphate. The following year they moved into Syria, taking the city of Damascus in March 1260.

By the summer of 1260, the Mongol force in Syria was much reduced in size. Because of the heat, the lack of grazing available, and because of unwelcome news from the Far East, its leader, Hülegü, and much of his army had withdrawn northwards. Hülegü left behind as his governor his experienced general, Kitbugha, who was, like Hülegü's wife Doquz Khatun, a Christian. Further south, the new rulers in Egypt, the Mamluk soldiers, had, after a decade of squabbling, managed to patch up their differences. Having humiliated and executed the Mongol emissaries sent to demand submission, the Mamluk Sultan Qutuz prepared to march northwards. His route would cross territory controlled by the Franks. The Frankish authorities in Acre faced a dilemma: throw in their lot with the Mongols, as Bohemond had done, and oppose the Mamluks; or make some sort of accommodation with Qutuz. Although the Mongols had only recently struck a blow at the heart of the Sunnī Muslim establishment, and had destroyed Muslim-ruled states all the way to Central Asia, the Franks of Acre had no reason to believe that the Mongols only targeted Muslims. Memories were still fresh of the appalling destruction meted out in central Europe in the 1240s. Frankish embassies sent to

mentioned by another text associated with the Armenian royal court, the chronicle attributed to King Het 'um II: in V. A. Hakobyan (ed.), Manr zhamanakagrut 'yunner XIII-XVIII dd. (Erevan, 1951), i, p. 82.

${ }^{3}$ On the attitude of the Franks of Acre to Bohemond's submission to Hülegü, and specifically that of the Papal Legate, Thomas Agni, bishop of Bethlehem, see Peter Jackson, "The Crisis in the Holy Land in 1260", English Historical Review, XCV (1980), p. 494.

${ }^{4}$ On the evidence for Het'um I being informed by Armenian sources about the impact of the Mongols, see Claude Mutafian "The Brilliant Diplomacy of Cilician Armenia", in Armenian Cilicia, (ed.) Richard G. Hovanissian and Simon Payaslian (Costa Mesa, 2008), p. 105.

${ }^{5}$ Submission to the Mongols did not, at this point, imply any great enthusiasm: the act of betrayal of the Seljuk royal women was not carried out with an easy conscience, but rather through fear of the consequences. This is clear from the account of Kirakos Ganjakets'i (Patmut'yun Hayots', (ed.) K. A. Melik'-Ohanjanyan (Erevan, 1961), p. 285) and that attributed to the king's brother Smbat ("Chronique du royaume de la Petite Arménie, par le Connétable Sěmpad", edited and translated by Édouard Dulaurier, in Recueil des Historiens des Croisades: Documents Arméniens 2 vols, (Paris, 1869-1906), i, p. 649). Even leaving this incident aside, it is likely that King Het'um's decision to submit to the Mongols and pay them tribute was because of fear of the likelihood of a Mongol attack on his lands: see, for example, the account of another contemporary writer, Grigor Aknerts 'i, where this is stated: "History of the Nation of the Archers", edited and translated by R. P. Blake and R. N. Frye, Harvard Journal of Asiatic Studies, XII (1949; also reprinted with corrections appended, Cambridge, Mass., 1954), p. 313. This material is discussed in more detail in Angus Stewart, "Alliance with the Tartars: The Armenian kingdom, the Mongols, and the Latins", in La Méditerranée des Arméniens, XII $I^{e} X V^{e}$ siècle, (ed.) Claude Mutafian, (Paris, 2014), pp. 208-209. 
the Mongols after this had been rebuffed with threats and demands for submission; even during the Mongol occupation of Syria the Frankish-held town of Sidon had been sacked. ${ }^{6}$ The Franks in Acre chose not to obstruct the Mamluk army, allowing it free passage.

On September 3, 1260, at c Ayn Jālūt in northern Palestine, the Mamluk and Mongol armies met. The result was unprecedented: defeat for the Mongols, with their commander, Kitbugha, found dead on the field. Syria was now opened up for Mamluk occupation: a new imperial power was established in the region. For their part Hülegü and his successors, the Ilkhans, repeatedly sought to regain Syria. ${ }^{7}$-After ${ }^{~}$ Ayn Jālūt Hülegü and his successors made extensive overtures to the Crusading powers of Western Europe, seeking potential allies against the Mamluks, which contrasted greatly with the earlier demands for submission sent by Mongol princes. The Armenians of Cilicia assumed a significant role in this diplomacy, often presenting themselves as vital intermediaries between the Franks and the Ilkhans ${ }^{8}$ and they did indeed continue to contribute to Ilkhanid invasions of Syria, at times with success albeit only ever transitory. ${ }^{9}$ The Ilkhans offered the Armenian kingdom a measure of protection, and the kings did make some initial gains under Ilkhanid patronage. They were, however, marked out by the Mamluks for revenge, along with other Mongol adherents. Syrian collaborators were executed; Antioch was destroyed in 1268; the Armenian kingdom, terrorised by raids and threatened raids, was forced into paying enormous tribute. ${ }^{10}$ But in 1260 , this was in the future.

\section{The Mongols at Hiromkla}

In this pivotal year, 1260, a Gospel Book, now in the Armenian Patriarchate in Jerusalem, was completed at the fortress of Hromkla, the headquarters of the Armenian Catholicos, Kostandin I, perched high above the Euphrates. ${ }^{11}$ The name of the artist who produced the volume, $\mathrm{T}^{\text {' }}$ oros Rōslin, is recorded in its colophon; and this is not his only surviving work. Seven signed manuscripts survive, dated between 1256 and 1268, and at least another one, and some fragments, have also been confidently attributed to him, or to his atelier. $\mathrm{He}$

\footnotetext{
${ }^{6}$ On this dilemma, see Jackson, "The Crisis in the Holy Land", especially pp. 503-507; also Jackson, The Mongols and the West (Harlow, 2005), pp. 119-123.

${ }^{7}$ On the development of the Mongol-Mamluk conflict, see Reuven Amitai-Preiss. Mongols and Mamluks: The Mamluk-İlkhānid war, 1260-1281 (Cambridge, 1995).

${ }^{8}$ On the development of Ilkhanid-Latin relations see, for example, Jackson, The Mongols and the West, pp. 165195; Paul Meyvaert, "An unknown letter of Hulagu, Il-Khan of Persia, to King Louis IX of France", Viator, XI (1980), pp. 245-259; Jean Richard, Au-delà de la Perse et de l'Arménie: L'Orient latin et la découverte de l'Asie intérieure (Turnhout, 2005), especially pp. 175-193; Richard, “D' Älğigidäi à Gazan: La continuité d'une politique franque chez les Mongols d'Iran”, in L'Iran face à la domination mongole, (ed.) Denise Aigle (Tehran, 1997), pp. 57-69.

9 On Armenian contributions to Mongol campaigns, see M. Canard, "Le royaume d'Arménie-Cilicie et les Mamelouks jusqu'au traité de 1285", Revue des études arméniennes IV (1967), pp. 223, 244; Amitai-Preiss. Mongols and Mamluks, pp. 183, 189; Angus Stewart, The Armenian Kingdom and the Mamluks (Leiden, 2001), pp. 136-152. These contributions could even be noted by Persian sources: see, for example, Rashīd al-Dīn's account of the Ilkhan Ghazan's invasion of Syria in 1299-1300, in W. M. Thackston's translation, Jami 'u'ttawarikh - Compendium of Chronicles, 3 vols (Cambridge, MA, 1998-99), iii, pp. 646-647.

${ }^{10}$ For details and translations of the treaty arranged in 1285 between King Lewon II and Sultan Qalawun, which arranged for the payment of this tribute, see Canard, "Le royaume d'Arménie-Cilicie", pp. 247-259; and P. M. Holt, Early Mamluk Diplomacy (1260-1290): Treaties of Baybars and Qalāwūn with Christian Rulers (Leiden, 1995), pp. 92-103.

${ }^{11}$ Gospel book copied for Catholicos Kostandin I, Hromkla, 1260 (Jerusalem, Arm. Patr. 251). On this work, see N. Bołarean, Mayr ts 'uts'ak dzeüagrats'Srbots' Yakobants' 11 vols (Grand Catalogue of St. James Manuscripts) ( Jerusalem, 1966-1995), ii, pp. 14-23.
} 
worked mainly at Hiromkla, and his surviving works were all commissioned for members of

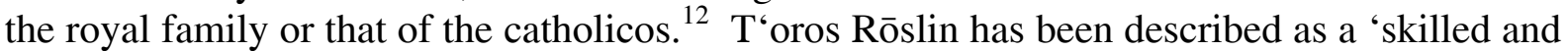
imaginative artist', and 'one of the most creative artists of the Middle Ages'. ${ }^{13}$ In comparison with his predecessors his compositions have greater liveliness and sense of drama, through "slight variations from the traditional iconographic scheme"; Der Nersessian states that "the main difference resides in the emotional content" of the work. ${ }^{14}$ While certainly working within the Near Eastern and Armenian tradition, he was capable of great originality in terms of compositional design. ${ }^{15}$ This was not merely originality for its own sake, but reflects close reading and interpretation of the relevant Biblical texts. ${ }^{16}$ In terms of choice of subject he reveals greater ambition than his immediate predecessors in Hromkla, who seem to have limited Gospel Book figural miniatures to the Evangelist portraits which served as frontispieces to the four Gospels. Nevertheless, while earlier Armenian artists included

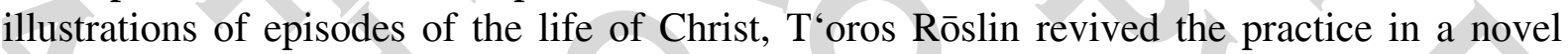
way. While the major scenes he depicts generally relate to the traditional Twelve Feasts, they are usually attached in the volume to the relevant text, rather than being arranged according to their chronological order in the liturgical year. ${ }^{17}$

Some evidence of iconographic innovation can also be seen in the Evangelist portraits themselves. While Der Nersessian suggests that T'oros Rōslin's Evangelist portraits in general reveal 'great sensitivity and originality', they generally conform to standard

\footnotetext{
${ }^{12}$ On T'oros Rōslin and his works, see Sirarpie Der Nersessian, Miniature Painting in the Armenian Kingdom of Cilicia 2 vols (Washington, 1993), i, pp. 51-76; see also Bazalel Narkiss (ed.), Armenian Art Treasures of Jerusalem (Oxford, 1980), pp. 47-54; and Dickran Kouymjian, Arts of Armenia, cap. 2, "Miniatures", section H, "Cilician Period" (http://armenianstudies.csufresno.edu/arts_of_armenia/miniatures.htm).

${ }^{13}$ Narkiss, Armenian Art Treasures, p. 47; Helen C. Evans, "Cilician Manuscript Illumination: the Twelfth, Thirteenth, and Fourteenth Centuries", in Treasures in Heaven: Armenian Illuminated Manuscripts, (ed.) Thomas F. Mathews and Roger S. Wieck (New York, 1994), p. 74.

${ }^{14}$ Der Nersessian, Miniature Painting, i, p. 58.
}

15 For example, see his depiction of the Harrowing of Hell in another Jerusalem manuscript, from 1265 (Arm. Patr. 1956, fol. 110), reproduced in Der Nersessian, Miniature Painting, Fig. 216; for a discussion of his innovations in composition, see Der Nersessian, Miniature Painting, i, pp. 61-66. Possible Western European

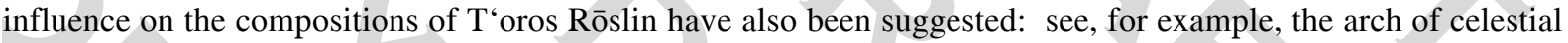
angels in the Nativity image from his 1260 Gospel Book discussed below, for which Western comparisons are identified by Levon Chookaszian, "L'art occidental, l'art français et la miniature arménienne du XIII siècle", in L'Église arménienne entre Grecs et Latins, fin XI $I^{e}-$ milieu XV $V^{e}$ siècle, (ed.) Isabelle Augé and Gérard Dédéyan (Paris, 2009), pp. 112-113. Sources of possible Latin Christian influence on T'oros Rōslin are also considered by Helen C. Evans, "Armenian Art Looks West: T'oros Roslin's Zēyt'un Gospels", in Treasures in Heaven: Armenian Art, Religion, and Society, (ed.) Thomas F. Mathews and Roger S. Wieck (New York, 1998), pp. 103114. The relationship of Armenian religious art and the Byzantine-mediated model is discussed in Dickran Kouymjian, "Armenian Gospel Illumination and the Classical Tradition", in Text and Context: Studies in the Armenian New Testament, (ed.) S. Ajamian and M. E. Stone (Atlanta, 1994), pp. 59-73; and also by Annemarie Weyl Carr, "Icon-Tact: Byzantium and the Art of Cilician Armenia", in Treasures in Heaven: Armenian Art, Religion, and Society, (ed.) Thomas F. Mathews and Roger S. Wieck (New York, 1998), pp. 73-102. Carr argues that "common characteristics unite the art of Byzantium and Armenia"; for example, "manuscripts display the biblical events in shared conventions that are as recurrent and recognizable as the words of the Bible itself"; and "as well as sharing this germinal Christian vocabulary, the two traditions were linked by recurrent artistic interchanges"; nevertheless, "the art of Byzantium and the art of Armenia are so different as to challenge the very utility of such phylogenetic abstractions" (p. 73). Part of the discussion of this thesis focuses on T'oros Rōslin, and specifically his Gospel Book of 1262, now in the Walters Art Gallery, Baltimore (MS W.539): pp. 84-92.

${ }^{16}$ See for example his introduction of portraits of Old Testament prophets to his depictions of the canon tables prophets whose texts relate typographically to the relevant New Testament episodes: Narkiss, Armenian Art Treasures, p. 51.

${ }^{17}$ Narkiss, Armenian Art Treasures, p. 53. Evans argues that "the most original aspect of Roslin's works ... is the richness of his narrative illuminations": "Cilician Manuscript Illumination", p. 74. 
iconographic types. ${ }^{18}$ The 1260 Gospel Book now in Jerusalem, however, deviates dramatically from the norm. The frontispiece to the Gospel of Matthew depicts not a simple portrait of the Evangelist but rather an image of the Nativity and Adoration, with Matthew himself relegated to a corner, in a compartment introduced beneath the main scene. ${ }^{19}$ This is not the first Gospel Book where we can see this conflation of the Nativity with the portrait of Matthew. A cluster of Byzantine manuscripts from Constantinople, produced in the early Komnenian period (late eleventh to mid-twelfth century) also display this feature. In these examples, however, all four Evangelist portraits are combined with scenes connected with the relevant author; the intention seems to have been to provide an illustration of the feast when the specific Gospel Book was read in the course of the liturgical year. ${ }^{20}$ In this case a different explanation must be found: in this 1260 work all the other Evangelists are presented conventionally, with full-page portraits. ${ }^{21}$

The main scene in this miniature, depicting the Nativity, is given a title near the top, just beneath the blue sphere representing the Divine Presence: "The Birth of the Lord" ${ }^{22}$ Its composition is, however, rather different from conventional accounts of the Nativity. If we compare this picture with other near-contemporary versions of the scene, some remarkable differences stand out. In the standard Near Eastern pattern, followed elsewhere by T'oros Rōslin, the Virgin is shown reclining, the Magi and the shepherds frame the centre, the washing takes place at the bottom, and Joseph sits reflecting in the corner. ${ }^{23}$ For this particular 1260 Gospel book, however, the artist has radically diverged from the tradition. The shepherds are relegated to the upper left, with their sheep merging into the mountain doubling as the canopy behind the Holy Family. The scene of "the Washing of the Lord" has been moved to the lower compartment, balancing the image of the Evangelist. In addition, the Virgin and Child are more upright in posture, and Joseph stands beside them. ${ }^{24}$ The

${ }^{18}$ Der Nersessian, Miniature Painting, i, p. 56.

19 [FIGURE 1] This image is at fol. 15v. See also Der Nersessian, Miniature Painting, Fig. 212; and Claude Mutafian, L'Arménie du Levant (XI'-XIV siècle) (Paris, 2012), ii, Fig. 122

${ }^{20}$ See Cecilia Meredith, "The Illustration of Codex Ebnerianus: A Study in Liturgical Illustration of the Comnenian period", Journal of the Warburg and Courtauld Institutes, XXIX (1966), pp. 419-424. For a discussion of points of comparison between miniatures by T'oros Rōslin and Byzantine manuscript illustration, especially concerning Evangelist portraits, see Levon Chookaszian, "L'Oeuvre de T'oros Rōslin et l'enluminure Byzantine”, Revue des études arméniennes, XXVIII (2001-2), pp. 399-424.

${ }^{21}$ For a more conventional frontispiece portrait of Matthew by T'oros Röslin, see, for example, the 1265 Jerusalem manuscript (Arm. Patr. 1956, fol. 14v), reproduced in Der Nersessian, Miniature Painting, Fig. 193. For reproductions of the other Evangelist portraits in the 1260 Gospel Book, see Narkiss (ed.), Armenian Art Treasures, Fig. 62 (Mark; fol. 102v); Der Nersessian, Miniature Painting, Fig. 192 (Luke; fol. 160v); and Der Nersessian, Miniature Painting, Fig. 186 (John; fol. 255v). According to Der Nersessian, the portrait of Luke in this manuscript is probably the work of an assistant: Miniature Painting, i, p. 57.

${ }^{22}$ The various other elements of the composition - the Shepherds, the midwives washing Jesus, etc. -are all described by labels as well, generally in less emphasised lower case, though the label for the infant Christ on his mother's knee is also in bold capitals.

${ }^{23}$ For example, see the version by T'oros Rōslin himself, in a Gospel Book from 1268 also commissioned by Kostandin I, now in Erevan (Matenadaran 10675, fol. 177; in Der Nersessian, Miniature Painting, Fig. 213); or an example from another Jerusalem manuscript (Arm. Patr. 2568, fol. 8v), by an unknown but different hand, but commissioned by Prince Vasak, who was also a patron of $\mathrm{T}^{\circ}$ oros Rōslin (in Der Nersessian, Miniature Painting, Fig. 380).

${ }^{24}$ This may reflect the tradition that the Magi visited the Holy Family a dozen nights after the nativity. While in the early Church the Adoration of the Magi was celebrated on the same day as the Nativity on January 6, by the thirteenth century, certainly in Western and Armenian traditions, the Nativity had moved to its earlier date while the Magi's arrival was still celebrated at Epiphany. See, e.g., the Armenian Synaxarion dated to 1269 by Kirakos Arewelts ‘i, in (ed) G. Bayan's translation, "Le Synaxaire Arménien de Ter Israel, V: Mois de Kalotz”, Patrologia orientalis, XVIII (1924), pp. 102-103 (Nativity - 17 k'ałots‘ / 25 December), pp. 186-192 (discussion of the dates of the Nativity and Epiphany), pp. 193-195 (Epiphany and arrival of the Magi - 29 
model followed in this image is more akin to the stand-alone Adoration image than that of the Nativity. ${ }^{25}$ In this 1260 Nativity/Adoration, the Three Magi are given more space than in a standard representation of the Nativity, and their role in the scene is accentuated.

This radical repositioning and reorganisation of the composition seems to emphasise its particular importance within the whole work. It should be noted that in this Gospel Book the only full-page panel illustrations are of the canon tables and the Evangelists - and this Nativity/Adoration. Furthermore, within the image itself the role of the Three Magi is stressed - indeed, in the blue quatrefoil, and thus standing out more than the central Nativity title, the image has a second title, in capitals: "the Magi came from the East". ${ }^{26}$ The Magi themselves are depicted conventionally, as representatives of three ages of man: one more elderly, with a full beard, presenting his gift; the second, middle-aged and more tidilybearded; and the third, youthful and beardless. This tradition "emphasises the fact that revelation is given to men independently of their years and worldly experience". ${ }^{27}$ The most remarkable feature of the whole composition, however, is the retinue that accompanies the Magi. Sirarpie Der Nersessian, in her short description of this image, calls attention to this interesting feature, though she does not see it as especially significant.

Whether or not Rōslin was familiar with the apocryphal Infancy Gospels, mentioning the large company of soldiers that accompanied the kings, he would naturally have assumed that they would not have come from a distant land without a bodyguard. ${ }^{28}$

This may seem, perhaps, too conservative an explanation. For one thing, $\mathrm{T}^{\prime}$ oros was quite capable of painting this scene without this 'bodyguard' - this is the only surviving example of his depiction of this scene in which he includes it - though in an illustration of a different episode, the departure of the Magi, in another Gospel Book from 1262, he does indeed depict the Magi accompanied by a bodyguard, if one of a rather different and much more explicitly military character. ${ }^{29}$ The introduction of this retinue in this Nativity has disrupted the composition: in order to balance it, the artist has had to rearrange the shepherds, or, possibly to introduce them -their gestures seem to echo that on the other side. Introducing such a novel element as this retinue would not, surely, have come naturally, and may have had greater intended resonance.

It is worth looking in more detail at these five men. A label clearly identifies them: they are $T^{\prime}$ 'at'ar, Mongol. Again, for Der Nersessian, it was logical that T'oros Rōslin should represent these men "with the facial type and costume of the oriental people best known to him, namely the Mongols, the allies of the king of Cilicia". 30 This may, of course, be the

k'ałots" / 6 January). See also Lars Bisgaard, "A Black Mystery: the Hagiography of the Three Magi”, in Medieval History Writing and Crusading Ideology, (ed.) Tuomas M.S. Lehtonen and Kurt Villads Jensen (Helsinki, 2005), p. 121.

${ }^{25}$ For two more conventionally arranged versions of this by T'oros Rōslin, see the Washington Freer Gallery Adoration (Ms. 32.18, pp. 8-9; attributed to Rōslin, and dated to ca 1268; in Der Nersessian, Miniature Painting, Fig. 183); or the Erevan Adoration of 1268 (Matenadaran 10675, fol. 19; in Der Nersessian, Miniature Painting, Fig. 184).

26 "Mogk" yarevelits " ekin". Note that the label for the Evangelist portrait in the compartment below the main scene, "St Matthew writes his Gospel" (sbn Mat'eos grè ziwr av etarann), is similarly emphasised by a blue background.

${ }^{27}$ Leonid Ouspensky, in idem and Vladimir Lossky, The Meaning of Icons (revised edition, Crestwood, New Yoir, 1983), p. 160.

${ }^{28}$ Der Nersessian, Miniature Painting, i, p. 60.

${ }^{29}$ Baltimore, Walters Art Gallery 539, fol. 19; reproduced in Der Nersessian, Miniature Painting, Fig. 215.

${ }^{30}$ Der Nersessian, Miniature Painting, i, p. 60. 
case. On the other hand, the entourage in the 1262 Gospel Book's illustration of the departure of the Magi does not consist of Mongols, but rather helmeted soldiers carrying banners: Der Nersessian concludes that "here he has visualised the scene as an event taking place in his own time and his own country". ${ }^{31}$ This would suggest that, contrary to Der Nersessian's earlier judgement, there was indeed something noteworthy about the choice of Mongols to accompany the Magi in this Nativity image. Furthermore, it should be noted that King Het 'um was not so much the ally of the Mongols as their subject, as is indicated explicitly in the Gospel Book's colophon, where it is stated that it was completed at the time of "the tyranny of the great prince called Manku [Möngke] and the world-conqueror Hołayun [Hülegü] his brother". ${ }^{32}$ The Mongol princes are named, appropriately, before mention is made of King Het'um. This notice certainly highlights also the importance of the Mongols at the time and place in which this Nativity was painted, which may suggest that the image, or rather the presence within it of these Mongols, should be interpreted as having some considerable significance.

In the Nativity image, the Tatar retinue of the Magi are by no means uniformly depicted: one expresses amazement, his finger on his lips, looking on the Holy scene; others look up at the star that has led them, shining down on the infant; one, wearing a black cap with gold trim, pointing up to the star (or is it the quatrefoil with the title?), seems to be calling his companions' attention to it - or, possibly, explaining it to them. ${ }^{33}$ In contrast to the labels of all the other elements in the picture, which are straightforward, and merely descriptive, the label identifying these as Mongol, however, as an original feature, follows no established pattern, and presents something of a mystery: Dumpunl / tintil mJ / umLn - T'at'arn/erek ay/sawr. This can be translated as "the Tatar came today". ${ }^{34}$ Bezalel Narkiss suggests that the "inscription seemed appropriate to Thoros, as he probably associated "the Magi who came from the East', the inscription on the left, with the Mongol Tatars". ${ }^{35}$ As we have seen, however, this is the only one of his works where this association is evident. Claude Mutafian is surely correct to see something of greater significance in this text, asking whether this singular arriving Tatar could have been Hülegü, tentatively identifying the Tatar in the image distinguished by his black and gold cap and pointing up at the escutcheon indicating "the Magi who came from the East" as a portrait of the Ilkhan himself. ${ }^{36}$ It is entirely possible that Hülegü may have visited Hromkla. The Syriac ecclesiastic and chronicler, Bar Hebraeus, tells us that, on Hülegü's advance into Syria in late 1259, he ordered pontoon bridges to be constructed across the Euphrates at Melitene, Hromkla, al-Bīra (near ancient Belkis-Zeugma), and, much farther to the south, Qarqiisiyya (ancient Circesium). ${ }^{37}$ The completion of this Gospel book in the following year, 1260, is attested to in the colophon, which of course refers to Möngke and Hülegü. ${ }^{38}$ This image could then conceivably commemorate a meeting between catholicos and Ilkhan. It may also be that in Hromkla this encounter was anticipated as being symbolic of a decisive shift in the region,

\footnotetext{
${ }_{32}^{31}$ Der Nersessian, Miniature Painting, i, p. 61.

32 Bołarean, Mayr ts 'uts'ak dzeüagrats' Srbots' Yakobants', ii, pp. 17-18.

${ }^{33}$ For the former interpretation, see Der Nersessian, Miniature Painting, i, p. 60.

${ }^{34}$ Claude Mutafian translates it as 'le tatare est arrivé aujourd'hui': L'Arménie du Levant, i, p. 147, and ii, Fig. 122.

${ }_{35}$ Narkiss, Armenian Art Treasures, p. 52; Narkiss translates the label as "the day when the Tatars are coming".

${ }^{36}$ Mutafian, L'Arménie du Levant, i, p. 147, asks if "ne serait-ce pas là Houlagou lui-même, ainsi identifié à un Roi mage qui serait le Tatare [... ] arrive aujourd'hui?"

${ }^{37}$ Bar Hebraeus, The Chronography of Bar Hebraeus, 2 vols., edited and translated by E. A. Wallis Budge (London, 1932), i, p. 435.

${ }^{38}$ Bołarean, Mayr ts 'uts' 'ak dzeüagrats' Srbots 'Yakobants', ii, pp. 17-18.
} 
likely to be to the benefit of the Christian communities - and especially the Armenians, loyal subjects of the Great Qaghan. ${ }^{39}$

Certainly it is clear that Mongol, and then Ilkhanid, imperial culture was to have a notable effect on artistic production in Armenian Cilicia. For example, by the 1280 s at least Chinese motifs were being integrated into Armenian manuscript illustrations, both in a merely decorative and in a meaningful way, and this may even pre-date evidence for such influence in works from the Islamic Near East. It is likely that this influence came both directly from works, such as silks, originating in the Far East, and from works created for the Ilkhans in Persia, such as have been found at the palace complex at Takht-i Sulaymān. It may even be that Chinese models, mediated through the Mongol court, contributed to a stylistic change in painting within the Armenian kingdom in Cilicia in the late thirteenth century as well as the introduction of new motifs. ${ }^{40}$ It is also possible that this Mongol influence eventually had an effect beyond the field of high status manuscript illustration: it may be that fabrics produced

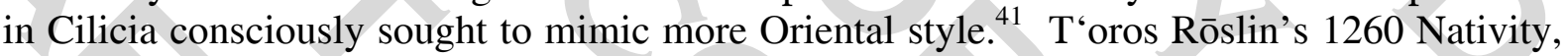
however, seems to be the only surviving example of the depiction of identifiably Mongol figures depicted in Armenian religious art at this time. ${ }^{42}$

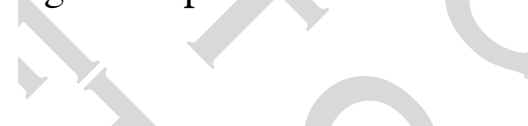

${ }^{39}$ Mutafian, L'Armenie du Levant, i, p. 147, suggests that T'oros Rōslin must have attended the meeting between
Hülegü and the catholicos - assuming such a meeting took place. He also suggests that "l'arrivée de l'armée tatare étant perçue comme une providence".

${ }^{40}$ Dickran Kouymjian argues that these new motifs of Chinese origin in Armenian miniatures were not used ignorantly, but rather their symbolic meaning was fully understood and exploited. This argument is developed in a series of articles: "Chinese Elements in Armenian Miniature Painting in the Mongol Period", in Armenian Studies/Études Arméniennes: In Memoriam Haïg Berbérian, (ed.) Dickran Kouymjian (Lisbon, 1986), pp. 41586; "Chinese Motifs in Thirteenth Century Armenian Art: the Mongol Connection", in Beyond the Legacy of Genghis Khan, (ed.) Linda Komaroff (Leiden, 2006), pp. 303-324; "The Intrusion of East Asian Imagery in Thirteenth Century Armenia: Political and Cultural Exchange along the Silk Road", in The Journey of Maps and Images on the Silk Road, (ed.) Phillippe Forêt and Andreas Kaplony (Leiden, 2008), pp. 119-133; "Chinese Dragons and Phoenixes among the Armenians" in Civilizational Contribution of Armenia in the History of the Silk Road, (ed.) A. A. Melk'onyan (Erevan, 2012), pp. 227-253. In the latter essay the relationship of iconography found in the Takht-i Sulaymān tiles and in Armenian miniatures is discussed at length.

${ }^{41}$ For the suggestion that silks produced in Cilicia in the early fourteenth century were produced after a 'Tartar' fashion, see David Jacoby, "Silk Economics and Cross-Cultural Artistic Interaction: Byzantium, the Muslim World, and the Christian West", Dumbarton Oaks Papers, LVIII (2004), p. 233.

${ }^{42}$ It has been suggested that such use of specifically Mongol figures in a Christian context may not be unique in the contemporary Near Eastern context. Jean Maurice Fiey identified an image of Helena and Constantine with the True Cross in a Syriac lectionary now in (Bibl. Apostolica Vaticana; Vat. sir. 559, f. 223v), which he dates to 1260, as being in effect a double portrait of Hülegü and his Christian wife Doquz Khatun: J. M. Fiey, "Iconographie Syriaque: Hulagu, Doquz Khatun ... et six ambons?", Le Museon, LXXXVIII (1975), pp. 59-68; for an illustration in colour of this image, see G. Lenzi, "Lezionario dei Vangeli. Siriaco", in I Vangeli dei Popoli: La parola e l'immagine del Cristo nelle culture e nella storia, ed. Francesco D' Aiuto, Giovanni Morello and Ambrogio M. Piazzoni (Vatican City, 2000), p. 309, Fig. 75. Fiey's identification here is based on Constantine's Mongol physiognomy, and the couple's robes, which show oriental designs. It is clear that Doquz Khatun did have a very good reputation among Christians in the Near East. Contemporary Armenian sources, for example, note how she intervened on behalf of the Christian population of Baghdad to prevent their massacre: see for example, Vardan Arewelts ‘i, in Robert W. Thomson's translation "The Historical Compilation of Vardan Arewelc ‘i”, Dumbarton Oaks Papers XLIII (1989), p. 217; Kirakos Ganjakets ‘i, Patmut'yun Hayots', (ed.) Melik'-Ohanjanyan, p. 382. Another Armenian observer, Step'annos Orbēlean, even went so far as to refer to the pair as being "not any less in piety than Constantine and his mother Helena", while referring to Hülegü as "the great and pious conqueror, the hope and expectation of Christians", and describing Doquz as 'all-blessed': Patmut'iwn nahangin Sisakan arareal Step 'annosi Orbēlean ark'episkopi Siwneac', (ed.) K. Šahnazareanc' (Paris, 1859; reprinted Tiflis, 1910), p. 419. That such sentiments were recorded at the time, albeit in a different Near Eastern Christian community, may nevertheless add some reinforcement to interpretation of this image as an intentional symbiosis of Christian Roman and Mongol royalty. 


\section{A Mongol Magus at St Catherine's, Mount Sinai}

Perhaps more comparable with the 1260 Nativity by T'oros Rōslin is a third image, recently also dated to 1260. It too, remarkably, is a combined Nativity and Adoration. This is an icon from St Catherine's, Mount Sinai, one of the scenes painted on an Iconostasis Beam, made apparently to sit on top of the screen in a chapel, perhaps the special Frankish chapel in the monastic complex; it is generally thought to have been produced in St Catherine's. ${ }^{43}$ Kurt Weitzmann compares the style of the painting with a Venetian work from the 1290s, and proposes a Venetian or Venetian-trained artist, although the rather more solid figures, and some iconographic details suggest to him a slightly earlier date: roughly 1250 to $127 .^{44}$ More recently, however, Jaroslav Folda attributes the work to a "Crusader ... artist working in a Veneto-Byzantine Crusader style", relating it to work thought to originate in Acre in the 1250s. ${ }^{45}$ Many of the scenes depicted on the beam follow the standard Byzantine iconographic model, but this one, of the Nativity and Adoration, demonstrates some novel iconographic choices. Overall this version is closer in layout to the standard Nativity, with

Interestingly, the contemporary Syriac observer of (and, at Aleppo, unwilling participant in) these affairs, Bar Hebraeus, does not mention Doquz Khatun as the protector of the Christians of Baghdad - the credit is given to the (Syriac) Catholicus - but he does later state that she was noted as a "believing queen and lover of Christ": Chronography, translated by Budge, i, pp. 431, 435. Similarly, the Armenian Grigor Aknerts 'i does not refer to Doquz Khatun's intervention at Baghdad, but later states that Hülegü "was very good, loving Christians, the church, and priests" (something of a theme in this work) and also that "his blessed wife ... was good in every way ... [and] very much loved all Christians, Armenians and Syrians, so that she had a tent church and a sounder [of the call to mass] who travelled with her, and many Armenian and Syrian priests": "History of the Nation of the Archers", edited and translated by Blake and Frye, pp. 340-341 (see also p. 178 of the 1954 reprinting).

Nevertheless, it is not at all clear that Fiey's interpretation of this image should be accepted. This Vatican manuscript has a very close relationship with another lectionary (London, B.L. Add. 7170), which includes a very similar image of Constantine and Helena with Central Asian appearance, but which is securely dated to 1215-22. This suggests that, even if the Vatican lectionary is dated to 1260 , rather than being a response to current affairs this depiction of Constantine and Helena represents a pre-Mongol iconographic tradition, perhaps relating to contemporary Islamic depictions of Seljuk-era Turkish rulers. On these two manuscripts, and their relationship, see, e.g., Hugo Buchtal, "The Painting of the Syrian Jacobites in relation to Byzantine and Islamic Art”, Syria XX (1939), pp. 136-150; Jules Leroy, Les manuscrits syriaques à peintures conserves dans les bibliothèques d'Europe et d'Orient (Paris, 1964), pp. 280-313; and now Bas Snelders, Identity and ChristianMuslim Interaction: Medieval Art of the Syrian Orthodox from the Mosul Area (Leuven, 2010), pp. 151-213.

${ }^{43}$ [FIGURE 2] For a colour reproduction, see Kurt Weitzmann, "The Icons of the Period of the Crusades", in The Icon, (ed.) Weitzmann et al. (New York, 1982), p. 221. The beam as a whole is discussed in the context of other such beams at Sinai by Kurt Weitzmann, "Icon Programs of the $12^{\text {th }}$ and $13^{\text {th }}$ Centuries at Sinai", Deltion tēs Christianikēs Archaiologikēs Hetaireias, XII (1984), pp. 82-86; the Nativity icon is briefly discussed. Another discussion of this beam, alongside another one also thought to be 'crusader' work, is by Barbara Zeitler, "Two Iconostasis Beams from Mount Sinai: Object Lessons in Crusader Art", in The Iconostasis: Origins Evolution - Symbolism, (ed.) Alexei Lidov (Moscow, 2000), pp. 223-242. The whole beam is discussed by John Cotsonis, and reproduced in colour, in Byzantium: Faith and Power (1261-1557), (ed.) Helen C. Evans (New York, 2004), pp. 362-363, and Fig. 220.

${ }^{44}$ Kurt Weitzmann, "Icon Painting in the Crusader Kingdom", Dumbarton Oaks Papers, XX (1966), p. 62. In contrast, Zeitler points out that there is no evidence that the beam was made at or for Sinai, nor that a designated Latin-rite chapel existed there in the thirteenth century: "Two Iconostasis Beams", pp. 227-230

45 Jaroslav Folda, Crusader Art in the Holy Land, from the Third Crusade to the fall of Acre, 1187-1291 (Cambridge, 2005), p. 318. See also Jaroslav Folda, "The Figural Arts in Crusader Syria and Palestine, 11871291: Some New Realities", Dumbarton Oaks Papers, LVIII (2004), pp. 315-331; and Folda, "Crusader Artistic Interactions with the Mongols in the Thirteenth Century: Figural Imagery, Weapons, and the Çintimani Design", in Interactions: Artistic Interchange Between the Eastern and Western Worlds in the Medieval Period, (ed.) Colum Hourihane (Princeton, 2007), pp. 147-166. Zeitler problematises the concept of 'crusader' icons and challenges the assumption that this beam must necessarily have been the work of a Latin-rite artist: "Two Iconostasis Beams", pp. 232-234. 
the Virgin shown reclining. Angels fill the sky, and one announces the event to the shepherds, at the right; as in the Book of Isaiah, the calf and ass recognise the Lord in the centre; below, Joseph sits, and there is the scene of the washing. Into this, the star shining from the visible part of the Heavenly sphere has led the three Magi from the east, that is, the right.

These Magi are far from conventionally depicted, however. Normally, apart from the difference in ages and facial hair, the Magi are not distinguished from each other - in illustrations in the Latin West they are generally all crown-wearing kings; in the Byzantine world they wear vaguely Oriental costume befitting their origins. ${ }^{46}$ With the Sinai icon, one's attention is immediately drawn by the third magus, who, according to Weitzmann, "with a drooping mustache, sparse beard, slit eyes, and strange headgear is obviously a Mongol". ${ }^{47}$ Weitzmann puts this into the context of papal and French royal missions to the Mongols, but more specifically identifies this magus as the Mongol general Kitbugha, who was "a Nestorian Christian who claimed to be a descendant of one of the three Magi", ${ }^{8}$ and who moreover had demonstrated his favour to the Christians in the course of the sack of Baghdad and the occupation of Syria. The second Magus is also unconventionally distinct: he is a 'Westerner', with a black pointed beard and an ermine fur cap. Weitzmann suggests that this was intended as a portrait as well, of a 'Crusader', but the numerous possibilities preclude an attempt at identification. Nevertheless, Weitzmann concludes, with Kitbugha and this Frank side-by-side - they are even turned towards each other - "the Nativity picture becomes an expression of the oecumenical hopes of the Pope, St Louis, and all the Crusaders that an alliance with the Mongols would be a first step toward making Christianity the world religion". 49

For Folda the icon is less a reflection of such a grand objective than a commemoration of a specific event. ${ }^{50}$ He accepts the identification of Kitbugha as the third Magus, observing that "he has the Mongol physiognomy and wears a characteristic Mongol cap", and noting that he "was said to be descended from one of the three Wise Men from the East". 51 He also identifies the other two Magi. The second, in 'Italianate' costume, is identified as Bohemond VI, prince of Antioch-Tripoli. Folda refers to the ultimately 'Italian' ancestry of the princely house of Antioch, by which he may intend the foundation of the principality by the southern

\footnotetext{
${ }^{46}$ On the development of the representation of the Adoration of the Magi/Three Kings, see, e.g., Gertrud Schiller, Iconography of Christian Art, translated by Janet Seligman (London, 1971), I, pp. 94-117. For an account of the development in the West of the idea that the three Magi were of royal stock, see, e.g., Bisgaard, "A Black Mystery", p. 122; Bisgaard suggests that while the attribution can be seen earlier, in illustrations it was more especially from the "tenth and eleventh century ... that crowns began to appear on their heads". Certainly, by the twelfth century, and the development of the cult of the Three Kings at Cologne, this representation had become commonplace.

${ }^{47}$ Weitzmann, "Icon Painting", p. 63.

48 Weitzmann, "Icons of the Period of the Crusades", p. 204. See also Der Nersessian, Miniature Painting, i, pp. 60-61, n. 46, where Weitzmann's identification of the Sinai Mongol Magus as Kitbugha is rejected. Folda responds explicitly to this criticism: Crusader Art, p. 634, n. 711. Neither note, however, provides a convincing account of contemporary confessional and diplomatic politics. Zeitler states that "suggestion ... that this figure represents the Mongol general Kitbuqa ... is surely fanciful”: "Two Iconostasis Beams", p. 226.

${ }^{49}$ Weitzmann, "Icon Painting", p. 63. This passage is also quoted by Folda: Crusader Art, p. 321; "Figural Arts", p. 324; "Crusader Artistic Interactions", p. 149.

${ }^{50}$ Folda's argument is given in "Figural Arts", pp. 323-329; and Crusader Art, pp. 320-324. The two versions are identical in places.

${ }^{51}$ Crusader Art, p. 321; also, "Figural Arts", p. 326: "His physiognomy is characterized as Mongol, and he wears a typical Mongol cap". For a discussion of what this 'typical' Mongol cap may have been, and how it was perceived, see Angus Stewart, "If the Cap Fits: Going Mongol in Thirteenth Century Syria", Journal of the Royal Asiatic Society, Series 3, XXVI (2016), pp. 137-146; these images are discussed at pp. 144-146.
} 
Italian Norman Bohemond of Taranto. Even if this may seem to be a little far-fetched, it is clear that the princes in the mid-thirteenth century certainly had a close relationship with Italy. Bohemond VI's mother, Lucy, was of the family of the counts of Segni (and therefore a relative of Pope Innocent III and two other thirteenth-century popes); her brother, a bishop of Tripoli, was notorious among local Franks for his immoderate favouring of Italians, and this fed the simmering conflict between the prince and the barons of Tripoli. ${ }^{52}$ Whether Italianate costume reflects Norman ancestry, contemporary political alignment, or just local fashion, there are other reasons why Bohemond VI might be depicted next to Kitbugha. Bohemond, of course, was the Frankish prince who supported Hülegü's invasion of Syria in 1260. Bohemond's participation, moreover, had been encouraged by the neighbouring Christian king, his own father-in-law, Het 'um I of the Armenians - and this is the figure Folda sees depicted as the most senior of the three Magi. Het'um was indeed about 45 at this time - not, perhaps, as old as the Magus illustrated, but, Folda assumes, probably the senior in age of the three identified figures. While this figure is the most conventionally depicted, Folda points out that other depictions of Het'umians show them in cloaks of a similar red to that worn by this figure.

Folda goes further than this mere identification. He seeks to relate the image to a passage in the 'Templar of Tyre' section of the Gestes des Chiprois, describing the triumphal entry of the Mongol army into Damascus in 1260, in which Kitbugha was accompanied by Het"um I and Bohemond VI. Bohemond, we are told, desecrated several mosques, and converted one back into a church.

The king of Armenia and the prince of Antioch joined the Tartar host and were at the taking of Damascus. When Damascus fell, the prince - out of contempt for the Saracens, to shame them - had a most lovely church purified and censed. This church was from the time of the Greek Christians, from the time when Heraclius had had Damascus fortified; the Saracens had worshipped Muhammad in it, but it was originally the church of the Greeks. He had Frankish mass sung within it, and had its bells rung. And in other Mohammedan mosques, where the Saracens worshipped, he had pack-horses and donkeys stabled, and splashed wine on the walls and smeared them with pork, both salt and fresh. And where he commanded his men to commit one act of defilement, they did ten. ${ }^{53}$

This passage was, of course, written some decades later; not all commentators are willing to accept the 'Templar of Tyre' at face value here. While, for example, contemporary Arabic accounts from Syria mention the resentment of Damascus's Muslim population at the ostentatious joy shown by their Christian fellow-citizens at the Mongol occupation, the acts of desecration of mosques are not recorded, as one would certainly expect them to be. The Arabic sources are not restrained, for example, in detailing the atrocities, such as the burning of the Great Mosque, inflicted on Aleppo by the Armenian king in the course of this invasion; there seems no reason why they would neglect the opportunity to recount such events in

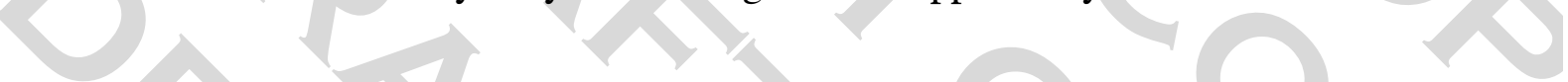

${ }^{52}$ For the conflict in the county of Tripoli, see for example, the account of the Gestes des Chiprois, (ed.) Gaston Paris, Louis de Mas Latrie and Charles Kohler, in Recueil des historiens des croisades: documents arméniens 2 vols. (Paris, 1869-1906), ii, pp. 748-750; in general, see, e.g., Jean Richard, The Crusades, c. 1071-c. 1291, translated by J. Birrell (Cambridge, 1999), pp. 461-462.

${ }^{53}$ Paul Crawford (translator), The 'Templar of Tyre': Part III of the 'Deeds of the Cypriots' (Aldershot, 2003), pp. 34-35; see also the Gestes des Chiprois, (ed.)Paris, Mas Latrie and Kohler, p. 751.
} 
Damascus. ${ }^{54}$ One contemporary Arabic writer, Ibn ${ }^{\mathrm{c}} \mathrm{Abd}$ al-Zāhir, goes so far as to provide an account of Bohemond of Antioch-Tripoli's activities in alliance with Hülegü, as an explanation for the decision of Baybars to launch an expedition against him in 1268; but there is no mention of this desecration in Damascus. ${ }^{55}$ It should also be pointed out that, while they present the conquest of Aleppo as violent and destructive, contemporary Armenian sources suggest that the occupation of Damascus by Hülegü was peaceful; it is not even clear whether King Het'um still remained with the Mongol army as far as Damascus. ${ }^{56}$ Modern scholars have not always been willing to accept the version of events at Damascus provided in the Gestes des Chiprois. For example, Peter Jackson states that while Bohemond may well have been present at the Mongol entry into Damascus, the story of his actions there as recorded by the 'Templar of Tyre' is 'demonstrably apocryphal'. 57

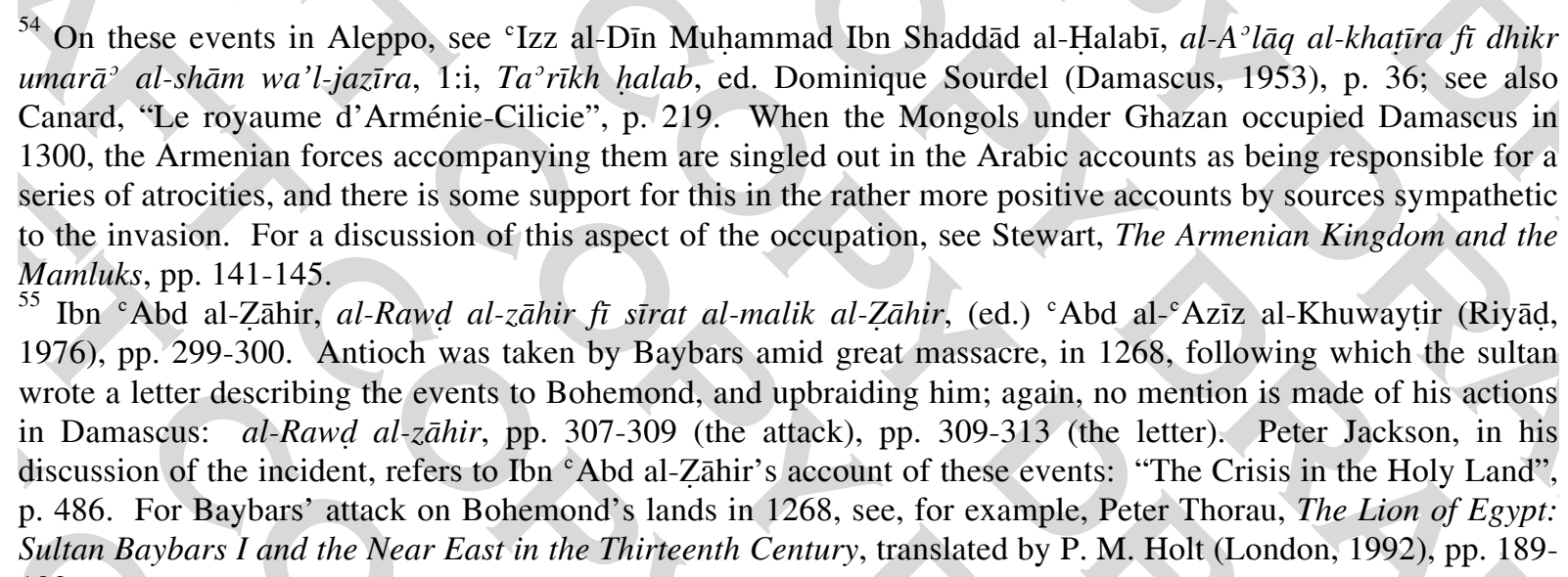
192.

56 According to the Chronicle attributed to Smbat Sparapet, Hülegü, accompanied by King Het'um, broke through the walls of Aleppo, and "entering the city they marched on the citadel and, drawing their swords, mercilessly slaughtered the nation of the Ismaelites", plundering the Christian population; "taking their booty and captives they proceeded to Damascus, and subjugated the towns ... as far as Jerusalem" (Der Nersessian, "The Armenian Chronicle", p. 160; see also La Chronique attribuée au connétable Smbat, translated by Dédéyan, p. 105). According to Kirakos Ganjakets 'i, Hülegü took Aleppo by storm and began to destroy it, but halted the destruction when the garrison in the citadel submitted. He then went to Damascus where he was received with tribute, peacefully: Patmut'yun Hayots', (ed.) Melik'-Ohanjanyan, pp. 387-388. According to Grigor Aknerts 'i, Hülegü's forces "took Aleppo, killed mercilessly, made captives, and gorged themselves on many treasures ... when the people of Damascus learned that they had taken Aleppo, then they themselves, of their own will, gave over the city" to the Ilkhan: "History of the Nation of the Archers", edited and translated by Blake and Frye, pp. 348-349. With regard to the length of Het'um's attendance on the campaign, Vardan Arewelts i, does state that when Hülegü "took all the country of Šam [Syria], there was also with him our crowned Het 'um, who freed from death the Christians ... in every place": Thomson (translation) "The Historical Compilation of Vardan Arewelc i”, pp. 217-218. There is, however, nothing explicitly said about his presence at Damascus. The colophon of T'oros Rōslin's Gospel Book of 1260, mentioned above, refers, after the notice of its completion in the reigns of Möngke and Hülegü, to "the divine and pious king of Armenia Het 'um, ... when he took the celebrated Halp [Aleppo], and all its cities and fortresses": Bołarean, Mayr ts "uts 'ak dzeüagrats" Srbots' Yakobants', ii, p. 18. The implication here is that the expedition was conducted by Het'um himself, which certainly accentuates his role; but no mention is made of Damascus - though, of course, this could be because the manuscript was completed before news of any happenings there reached Hromkla.

57 Jackson, The Mongols and the West, p. 117. In the same vein, Peter Thorau suggests that the account of the 'Templar of Tyre' is "as doubtful as [Bohemond's] actual presence" in Damascus at the time, pointing out that this is our only source for the event, "while all other sources, both Frankish and Arabic, are silent on the matter": Thorau, The Lion of Egypt, pp. 68-69. Nevertheless, the story has left traces in accounts of the Mongol conquest of the city. David Morgan cautiously, and without going into detail, mentions "the famous scene in which Damascus was entered by the Mongols and their allies, allegedly headed by three Christians", Bohemond, Het"um and Kitbugha, which "might have seemed to herald a new era for the fortunes of Christianity in the land of its foundation", pointing out, however, that this incident is only described in the Gestes des Chiprois: The Mongols (Oxford, 1986), pp. 154-155, and n. 34. J. J. Saunders, however, appears to take the story of the 
For Folda, however, this passage in the Gestes des Chiprois explains this icon of the Nativity and Three Magi. This iconostasis beam was, Folda proposes, commissioned by Prince Bohemond for his new, or newly restored, church in Damascus:

perhaps the wood for the beam was sent to Sinai from Tripoli at Bohemond's directive ... However it was effected, the commission was duly carried out in mid-1260, with the special imagery indicated to commemorate the triumphal entry of Kitbuqa, Hetoum and Bohemond. ${ }^{58}$

'Unfortunately', Folda continues, the battle of 'Ayn Jālūt intervened; with Kitbugha's death and the Mamluk victory, 'the dream of Christianity conquering the Near East, retaking the Holy City of Jerusalem, and making Christianity the dominant world religion through a Crusader alliance with the Mongols and the Armenians was now definitively over. ${ }^{59}$ This icon of the Three Magi remains as testimony to the hopes held in this brief interlude for such an alliance. Folda concludes by exclaiming:

What a vivid illustration of the vicissitudes of history that an iconostasis beam, apparently commissioned to decorate the sanctuary of a Christian church in Damascus could never reach its intended destination and instead remained in the monastery where it was painted, its original purpose apparently unrecognized for centuries! $!^{60}$

Folda's thesis does, however, present certain problems. For one thing, one might argue that the 'dream of ... a Crusader alliance with the Mongols and the Armenians', far from 'definitively over', was only just beginning to be dreamt seriously. More specifically, does this Mongol have to be Kitbugha, rather than, say, Hülegü? The former may famously have been a Christian, of sorts, but his master developed a reputation for favouring Christians, at least among Christians, and as we have seen has indeed been identified as the subject of Christian religious art elsewhere. Obviously if we accept that the icon commemorates the triumphal entry to Damascus as described by the 'Templar of Tyre', then Kitbugha would seem to be the better candidate; in addition, of course, Folda notes that he "was said to be descended from one of the three Wise Men'; or, as Weitzmann puts it, Kitbugha "claimed to be a descendant of one of the three Magi". This would certainly make him a suitable candidate for depiction as one of the Magi, but whether or not this was actually the contemporary belief is uncertain. Both Weitzmann and Folda cite Runciman's History of the Crusades for this information; and his source is a single text, written in France in $1307 .^{61}$ This text will be discussed below, but as with the passage from the Gestes des Chiprois it may

triumphal entry of the three at face value, and, without reference to sources, mentions that "one of the city mosques was converted into a Christian church": The History of the Mongol Conquests (London, 1971), p. 113. Joshua Prawer reports the whole story of the conversion of the mosque, and the actions of Bohemond and his followers in the city; on the basis that the source for the incident is itself Frankish, Prawer states that "Il n' $y$ a pas à mettre en doute la matérialité des faits": Histoire du royaume latin de Jérusalem, translated by G. Nahon (Paris, 1969-70), ii, p. 426, and n. 14. For a detailed recent discussion of these events, which separates the later actions of the Christian population of Damascus from the Gestes des Chiprois story, often confused in accounts of the Mongol occupation, see Dominique Sourdel, "Bohémond et les chrétiens à Damas sous l'occupation mongole", in Dei Gesta per Francos: Études sur les croisades dédiées à Jean Richard, (ed.) Michel Balard, Benjamin Z. Kedar and Jonathan Riley-Smith (Aldershot, 2001), pp. 295-299.

${ }^{58}$ Folda, "The Figural Arts", pp. 328-329; Crusader Art, p. 323.

${ }^{59}$ Crusader Art, p. 324; "Figural Arts", p. 329.

${ }^{60}$ Crusader Art, p. 324; "Figural Arts", p. 329.

${ }^{61}$ Steven Runciman, A History of the Crusades 3 vols. ( Cambridge 1951-54), iii, p. 300; cited by Weitzmann, "Icon Painting", p. 63; Folda, Crusader Art, pp. 321, 634; Folda, "Figural Arts", p. 326. 
represent the tradition of a later period, and a different geopolitical context. Furthermore, Folda's assumption about Kitbugha's age - the youngest Magus - is without foundation. Although Folda has stated that Kitbugha's age is unknown, ${ }^{62}$ we can get an impression of it from contemporary Syrian Arabic sources. For example, al-Yūnīnī, a Syrian eyewitness to Kitbugha's activities, provides a rather horrified description of him, and reports that he 'was an old man, reaching back to the time of Chinggis Khan'; this would suggest he was in his fifties at least in $1260 .^{63}$

While the interpretation of the image is not entirely dependent on the passage from the Gestes des Chiprois - Weitzmann does not mention it - there is a whiff of circularity about its use. On the one hand, the text supports, or even suggests, the interpretation of the icon; on the other hand, the icon reinforces the veracity of the text. As Folda states,
the passage in the Templar of Tyre is accurate and this painting ...
provides us with complementary evidence to verify the accuracy of
that report. Here we have "documented evidence" from both an
artistic work and a historical text to corroborate the record of an important event and to help us to understand the meaning of a remarkable image. ${ }^{64}$

This is fine - but only if one accepts the interpretation of the icon in the first place, independently of the Templar's text. Similarly, the dating of the iconostasis beam, while initially based on comparisons of style, is reinforced and made precise by this interpretation of this image; yet the relationship to the historical events was initially proposed by the dating. It should also be noted that the dating proposed by Weitzmann and Folda is not universally accepted. Valentino Pace, for example, states that it "is absolutely inconceivable" that work in this style could have been produced "at this early date of mid-Duecento"; he dates the beam "at the earliest, to the very end of the thirteenth century or, much more likely, the fourteenth". ${ }^{65}$ Folda argues against Pace in part because of the "relationship of this imagery with these historical developments", suggesting that if it must indeed be accepted as later work, it must then be a copy of a lost original. ${ }^{66}$ This, however, seems to neglect the fact that it was the dating that initially suggested the parallel with the account of the Gestes des Chiprois. In fact a later date, as Pace proposes, would make a relationship between the icon and the text more likely rather than less, as both would then reflect a tradition that had developed some time after 1260 - albeit one with a limited basis in actuality. At the same time, it could be argued that the inclusion of the Mongol figure alongside the Frank might be more representative of this later period, when the Ilkhans and Latins were actively working together in opposition to the Mamluk Sultanate. Certainly, if one does not tie the image to 1260 , there does not appear to be any necessity to connect it either to Kitbugha or to the capture of Damascus in that year.

There is a further complicating factor affecting the interpretation of this image. There is, as Barbara Zeitler has pointed out, no hard evidence that ties the beam's place of

\footnotetext{
${ }^{62}$ Folda, "Crusader Artistic Interactions", p. 150.

${ }^{63}$ Quṭb al-Dīn Mūsā al-Yūnīnī, Dhayl mir āt al-zamān fì ta ${ }^{3} \bar{r} k h$ al-a ${ }^{c}$ yān (4 vols; Haydarābād, 1954-61), ii, pp. 33-36; see Reuven Amitai, "An Arabic biographical notice of Kitbughā, the Mongol general defeated at ${ }^{\text {'Ayn }}$ Jālūt", Jerusalem Studies in Arabic and Islam, XXXIII (2007), pp. 219-234.

${ }^{64}$ "Figural Arts", p. 328.

${ }^{65}$ Valentino Pace, "Italy and the Holy Land: Import Export. I. The Case of Venice", in The Meeting of Two Worlds: Cultural Exchange between East and West during the Period of the Crusades, (ed.) Vladimir P. Goss (Kalamazoo, 1986), p. 333.

${ }^{66}$ Folda, Crusader Art, p. 635, n. 726.
} 
manufacture to Mount Sinai. Other icons in the monastery's collection originated elsewhere - for example, on Cyprus. ${ }^{67}$ Even the confessional identity of the artist, or their patron, may be unclear. While there are some iconographic elements that might imply that the beam was produced by and for Latin-rite Christians, Zeitler suggests that on their own these are not conclusive proof of the identity of either patron or artist, and might instead be indicative of the complex cultural milieu of the eastern Mediterranean region in the thirteenth century. ${ }^{68}$ The icon should perhaps be interpreted in this more general light. It may well be that the icon does not so much record and commemorate a specific event, but rather reflects a general direction of policy, or an aspiration of a more symbolic kind, for Believers of the Near East, the West and the Far East to be seen worshipping together before Christ. Perhaps Weitzmann was not so far off the point when he suggested that the icon represents hopes for a Mongol alliance, or a general ecumenical motivation - without, however, constraining it to a particular episode or event. Whatever the date of composition, or the identity of artist and patron, one might see this icon as evidence of the hopes invested in the region for the possibilities of Mongol intervention, or for their eventual conversion to Christianity.

\section{The Mongols, the Armenians, and the Magi}

A key factor linking the Armenian Gospel Book and the Sinai icon is the presence of Mongols relating to the Magi. In both cases this has been explained - for Der Nersessian it is a matter of coincidence; for Folda, and Weitzmann, it is because of Kitbugha's supposed Magian ancestry. Nevertheless, this association may be worth further consideration.

The irruption of the Mongols was frequently seen as a sign of impending apocalypse, in Latin, Armenian and other traditions, but this association with the Three Wise Men has a different, more optimistic flavour, perhaps echoing the early rumours about the imminent arrival of Prester John, or a Christian 'King David'. There were rumours that the attack on central Europe in 1241 was a campaign aimed at reaching the relics of the Three Kings in Cologne. The name given to the land of the Three Kings, 'Tarse', could become elided with the name Tatars - so the Mongols were, occasionally, called 'Tarsenses' ${ }^{69}$ The name recurs in the fourteenth-century English poem, The King of Tars, which appears to have nothing to do with Mongols, but which seems to have grown out of Latin tales of the Mongols and their alleged or hoped-for conversion to Christianity. Significantly, the Armenians often play a key mediating role in these tales - specifically, an Armenian princess is often the catalyst for the conversion of the Mongol king and the Christian reconquest of the Holy Land. ${ }^{70}$

Armenian writing on the Mongols, however, does not make the association between Mongols and Magi. Grigor Aknerts'i, for example, traces the Mongols back to the descendents of Hagar mingled with the people of Gog. ${ }^{71}$ For him, as with other accounts of the origins of the Mongol empire, Chinggis Khan's call for unification was divinely inspired;

\footnotetext{
${ }^{67}$ Zeitler, "Two Iconostasis Beams", p. 230; see also D. Mouriki, "Icons from the $12^{\text {th }}$ to the $15^{\text {th }}$ Century", in Sinai: Tresures of the Monastery, (ed.) Konstantinos A. Manafis (Athens, 1990), pp. 102-103.

${ }^{68}$ Zeitler, “Two Iconostasis Beams", pp. 232-234.; Zeitler's study of this and another beam concludes that "if these two epistyle beams tell us anything at all, it is that, within the specific circumstances of the eastern Mediterranean in the thirteenth century, we cannot pronounce with confidence whether an artist was Syrian, Greek or Venetian. Rather, these two beams emerge as products that are specifically Levantine and that, therefore, could have functioned in a variety of contexts".

${ }^{69}$ For all of this material, see Peter Jackson, The Mongols and the West, p. 138.

${ }^{70}$ For this tale, and a discussion of its analogues, see The King of Tars, (ed.) Judith Perryman (Heidelberg, 1980).

${ }^{71}$ Grigor Aknerts ‘i, "History of the Nation of Archers”, edited and translated by Blake and Frye, pp. 286-287.
} 
but the barbarous people he describes are not the descendants of the Magi. ${ }^{72}$ There are, however, exceptions to this rule: a letter written in 1248 in Samarkand by the Constable Smbat to his sisters and their Frankish Cypriot husbands, King Henry I and John of Ibelin, count of Jaffa, and passed by them to King Louis IX of France (on the island on crusade), and to the pope; and the Flor des estoires de la terre d'Orient of Het'um (or 'Hayton') of Korykos. ${ }^{73}$ Smbat refers to the wide dispersal of the Mongols, following their conquests:

Some of them [Mongols] were in India, others in the land of Chata [i.e., 'Cathay'], others in the land of Russia, and others in the countries of Chascat and of Tanghat which is the land from which the Three Kings came to Bethlehem to worship the Lord Jesus at his birth. You should know that Christ's power has been, and still is, great: the people of that country are Christians, and the whole of the land of Chata believes in the Three Kings. I myself have been in their churches and have seen paintings of Jesus Christ and of the Three Kings, one offering gold, another incense, and the third myrrh. It is through those Three Kings that they believe in Christ, and through them that the Khan and all his men have now become Christians. They have their churches in front of their gates, and sound their bells and beat their tablets, with the result that those who go to visit their lord the Khan have first to visit the church and salute the Lord Jesus Christ and only then go and salute their lord the Khan, whether they are Christians or Saracens, and those who disapprove of this [do it] willy-nilly. ${ }^{74}$

Hayton makes several references to the Three Kings in the Flor des estoires. At the beginning of Book I, when describing the lands of the Orient, he describes, bordering Cathay, the 'Kingdom of Tharse':

There are three provinces in the kingdom of Tharse, and the lords of these provinces are called kings, and they have a script and a language for each, and these people are called Jougour [Uighur]; and they have always been idolaters and they still are today, except for the nation of those 3 kings who came to worship at the nativity of Our Lord Jesus Christ, guided by the star. And there are still great lords among the Tartars of the lineage of these kings, who firmly believe in the faith of Jesus Christ. ${ }^{75}$
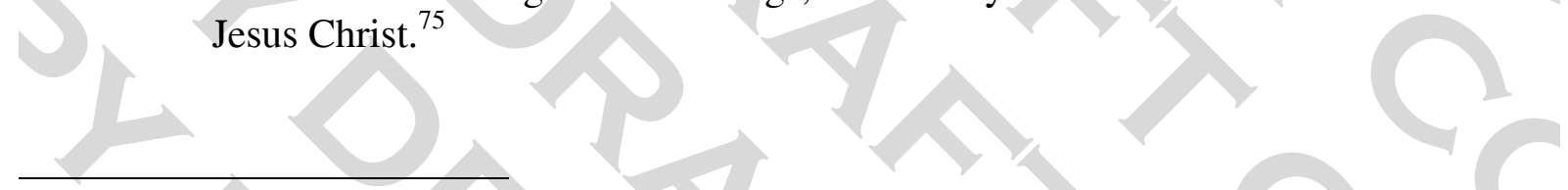

\footnotetext{
${ }_{72}^{72}$ Grigor Aknerts 'i, "History of the Nation of Archers", edited and translated by Blake and Frye, pp. 294-297.

${ }^{73}$ A critical translation of Smbat's letter, based on the various surviving versions, is in Jean Richard, "La lettre du Connétable Smbat et les rapports entre Chrétiens et Mongols au milieu du XIII ${ }^{\text {ème }}$ siècle", in Études arméniennes in memoriam Haïg Berbérian, (ed.) Dickran Kouymjian (Lisbon, 1986), pp. 688-692. Hayton's Flor des estoires is edited in Recueil des historiens des croisades: documents arméniens 2 vols. (Paris, 18691906), ii, pp. 113-366.

${ }^{74}$ Richard, "La lettre du Connétable Smbat", p. 690; translated in Peter Jackson, The Seventh Crusade, 1244-54: Sources and Documents (Farnham, 2009), pp. 78-79.

${ }^{75}$ The passage continues: 'The people of this land do not practice feats of arms, but are very skilled in the study of the arts and sciences. Most of them do not eat meat nor drink wine, nor do they kill any living thing. They have good and wealthy cities, and many great temples where they worship their idols that they hold in great reverence. In these lands wheat and other crops grow well, but they do not have vineyards, because they hold it a great sin to drink wine. This kingdom of Tharse is bordered to the east by the kingdom of Cathay; to the west by the kingdom of Turkestan; to the north by desert; to the south by a wealthy province called Sim, which is
} 
Later on, when describing Hülegü's occupation of Syria, he mentions on separate occasions how both Doquz Khatun and Kitbugha were "of the lineage of the 3 kings of the Orient who had come to Bethlehem to worship at the nativity of Our Lord". ${ }^{76}$ The context for these pronouncements is Doquz Khatun's patronage of Christian churches in Baghdad, and then Kitbugha's endeavour to recover the Holy Land, in which he was distracted by an unfortunate incident involving the sacking of Frankish Sidon - an incident Hayton works hard to explain away. $^{77}$

This, of course, is the source for Kitbugha's descent, used by Weitzmann and Folda via Runciman's History of the Crusades. The Flor des estoires is a remarkable text, and deserves much more attention; but its account of events a half-century before its composition should not, perhaps, always be accepted uncritically as accurate. ${ }^{78}$ It seems in these passages concerning Kitbugha and Doquz Khatun as if Hayton was attempting to explain the existence of senior Mongols who were Christians by attaching them to the story of the Three Kings. Similarly, while Hayton's 'kingdom of Tharse' may have some origin in the Uighur-ruled lands of the Tarim basin, that this appears in a work produced in France might suggest that it reflects a Frankish tradition, rather than Armenian insight. Similarly, Smbat's letter is a long attempt at ameliorating the unexpectedly hostile communication of the Qaghan Güyüg, and justifying the Armenian submission to this threatening empire; feeding his Frankish cousins stories that they might have been primed to accept was part of his method. Rather as the Mongols sought to tell the Franks what they thought the Franks wanted to hear about their confessional proclivities, here we have Armenians doing the same thing. ${ }^{79}$ That the two Armenian writers who refer to the Mongols in this way are writing for a clearly nonArmenian audience is significant; especially revealing is the terminology they use - not 'Magi', but 'Three Kings': using Frankish terminology, not Near Eastern, to make the point clear to the Franks.

The putative origin of the Three Kings in the land of "Tharse" as described by Smbat and Het 'um does not seem to help us explain the appearance of the Mongol Magus alongside Latin and Near Eastern ones on the Sinai icon, as, of course, in this account all three kings were from Central Asia. Nevertheless, written accounts such as these reflect the symbiosis of the stories of 'Prester John' and of the Three Kings. The phrase used by Hayton in his descriptions of both Doquz Khatun and Kitbugha seems almost to echo Otto of Freising's account of Prester John - the first mention of this individual in Western Europe: "it is said that he is a lineal descendant of the Magi, of whom mention is made in the Gospel, ... who came to adore Christ in his manger". ${ }^{80}$ As Western European knowledge of the lands

between the kingdom of Cathay and the kingdom of India; and in this land one finds fine diamonds.' Hayton, Flor, pp. 122-123.

${ }^{76}$ Hayton, Flor, pp. 169-170 (Doquz Khatun), p. 174 (Kitbugha).

${ }^{77}$ Hayton, Flor, p. 174; this account of the attack on Sidon is discussed by Jackson, "Crisis in the Holy Land", p. 485 (the circumstances of this event are analysed further at pp. 499-500).

${ }^{78}$ For a discussion of some of these themes, see Angus Stewart, "The Armenian kingdom and the Near East: Het "um of Gorigos and the Flor des estoires de la terre d'Orient", in Egypt and Syria in the Fatimid, Ayyubid and Mamluk eras, VII, (ed.) Urbain Vermeulen, Kristof D'hulster and Jo Van Steenbergen (Leuven, 2013), pp. $525-548$.

${ }^{79}$ On this, see Jackson, Mongols and the West, pp. 97-103, 175-176. Pope Innocent IV, in a letter of 1260, warned Edward, son of King Henry III of England, that the Mongols had a policy of simulating sympathy for Christians: see Thomas Rymer (ed.), Foedera, conventiones, litterae, et cujuscunque generis acta publica, inter reges Angliae et alios quosvis imperatores, reges, pontifices principes, vel, communitates habita aut tractata, I:i (revised edition, London, 1816), p. 403; and Jackson, Mongols and the West, p. 185

${ }^{80}$ Ottonis Episcopi Frisingensis, "Chronica sive Historia de Duabus Civitatibus", (ed.) Adolf Hofmeister, Monumenta Germaniae Historica: Scriptores Rerum Germanicum in usum scholarum, XLV (Hannover, 1912), pp. 366-367; translated by C. C. Mierow, The Two Cities: A chronicle of universal history to the year $1146 \mathrm{AD}$ 
encompassed by the Mongol Empire increased, and their confidence in the imminent arrival of a Central Asian 'Prester John' correspondingly declined, this figure was sought elsewhere, specifically in the Christian lands of east Africa, south of Egypt. ${ }^{81}$ It is at this time that we see the arrival of the black, African Magus in Western European art; and at this point, of course, in the fourteenth century, the Three Kings come to be seen as representatives of three different continents. ${ }^{82}$ It does not seem likely that this is what is being depicted with the Mongol and Frankish Magi at Sinai. Nevertheless it would, perhaps, be worth considering whether, if the Mongol Magus here is intended to depict a specific individual, that individual could be 'Prester John' himself, whose long-awaited arrival was anticipated to ameliorate the experience of the Christian population of the region. ${ }^{83}$

\section{Conclusions: The Coming of the Tatars}

This aggregation of the 'Three Kings', their land of 'Tharse', Prester John and the 'Tartars' seems to be more a feature of Latin response to the Mongols than of Armenian. Nevertheless, it should perhaps be borne in mind that the letter of the Constable Smbat, which makes some of these associations, pre-dates this 1260 Gospel book by a decade, and given the close relationship between Hromkla, and its scriptorium, and the Het'umians, it may not be too far-

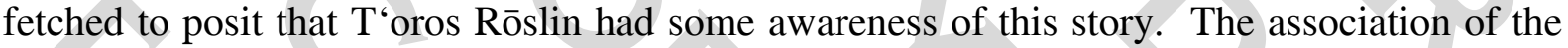
Magi and the Mongols in the Nativity image, however, seems to represent something different. While, as we have seen, Der Nersessian saw T'oros Rōslin's decision to grant the

by Otto Bishop of Freising (New York, 1928), p. 444. On the relationship of Prester John and the Mongols, see, for example, David Morgan, "Prester John and the Mongols", in Prester John, the Mongols and the Ten Lost Tribes, (ed.) Charles F. Beckingham and Bernard Hamilton (Aldershot, 1996), pp. 159-171; and Igor de Rachewiltz, "Prester John and Europe's Discovery of East Asia”, East Asian History, XI (1996), pp. 59-74.

${ }^{81}$ This development is traced, e.g., by Bernard Hamilton, "Continental Drift: Prester John's Progress through the Indies", in Prester John, the Mongols and the Ten Lost Tribes, (ed. Beckingham and Hamilton, pp. 237-269, especially pp. 252-53. See also Paul H. D. Kaplan, The Rise of the Black Magus in Western Art (Ann Arbor, 1985), pp. 51-58.

${ }^{82}$ For these developments in the representation of the Three Kings, see, e.g., Schiller, Iconography of Christian Art, p. 112. For the development of the Black Magus in Western European art, see, e.g., Kaplan, Rise of the Black Magus, pp. 85-101. While Kaplan does point to possible earlier examples, he concludes that the evidence "suggests that the invention of an image of the Black Magus occurred at some point between about 1340 and 1375 ", stressing that this coincides with textual affirmations of the idea, and also with "the growing tendency to place ... Prester John in black Ethiopia, which begins a few decades before 1340, but becomes the norm only after that date" (pp. 85-86). Kaplan later points out that the depiction of one of the Magi as black only became standard across Western European art by the early sixteenth century (pp. 112-119).

${ }^{83}$ Lucy-Anne Hunt has identified another example from this period of a Nativity scene where the Magi are differentiated in terms of their appearance, again in a Syriac context. The sanctuary wall painting of the Syrian Jacobite church of al- ${ }^{c}$ Adhrā ${ }^{\supset}$ at Dayr al-Suryan in Wadi al-Natrūn in Egypt, which has been somewhat tentatively dated to about $1225-50$, depicts the Annunciation and Nativity. In the latter, Hunt suggests that the third, youngest Magus has 'oriental' features: see Lucy-Anne Hunt, "Christian-Muslim Relations in Painting in Egypt of the Twelfth to mid-Thirteenth Centuries", Cahiers archéologiques: fin de l'antiquité et moyen âge, XXXIII (1985), p. 122. It is possible that this example, along with that from Sinai, represents evidence for a developing Near Eastern tradition; its dating may be suggestive of a relationship with the rumours circulating at the time in the Near East and reported by participants in the Fifth Crusade (in Egypt from 1218-21), concerning the imminent arrival of a force led by a 'King David', who was identified as the son of Prester John: see, e.g., Jackson, Mongols and the West, p. 48. It would be tempting to see the Sinai icon as a later example of the same thing. It may well be, of course, that even if the dating of the Dayr al-Suryan example is accurate, its simultaneity with the Fifth Crusade, and the circulation of these rumours, is merely coincidental. It should also be stressed that the identification of the third Magus as being 'oriental' here is much less clear-cut; his face is only very slightly differentiated, if at all, from the other two Magi, and his clothing is of a similar style. 
Magi a bodyguard, and to make this Mongol in appearance, as simple, logical decisions made in the composition of this Nativity, ${ }^{84}$ it seems possible that the reverse of this process is more accurate. The artist's intention was rather to include an image of the Mongols in this work, and the most logical place for them to appear was alongside the other visitors from the East, the Magi. T'oros then promoted this powerfully revised image to the frontispiece of the Gospel of Matthew, in order to stress further its originality and significance. The question remains, however, of why the decision was made to depict the Mongols in the first place.

The inscription identifying the entourage of the Magi - "the Tatar came today" - could, as we have seen, suggest that the miniature was intended to celebrate a specific event. That this event should have provided the motive for such a dramatic break from an artistic convention sanctioned by centuries of tradition seems extraordinary. It might have been more seemly, for example, for the event to have been recorded in a donor portrait. ${ }^{85}$ The image, of course, is primarily a Nativity: the most important 'arrival' is that of the Saviour - Christ, rather than Hülegü. More than merely commemorating a passing moment, T'oros Rōslin seems to be seeking to incorporate this new and threatening presence, the Mongols, into the Christian cosmos. This gets to the heart of the overall significance of the image, in design and context. The unconventional and prominent positioning of this image within the whole work - usurping the frontispiece from Matthew; the only narrative scene in this work compels the viewer to pay it extra attention; the unconventional composition emphasises the Magi, and especially their Tatar retinue, its most novel and dramatic feature.

It may have been the case that the enthusiasm felt by the Armenian élite for the Tatar yoke was rather less than untrammelled - at least initially, when there are hints in the sources that certain consequences of the relationship had to be accepted through gritted teeth. ${ }^{86}$ The presence of these Tatars in this image may simply reflect a political alignment which was becoming accepted and may even have seemed promising. While the works of the constable Smbat and Het "um of Korykos sought to justify and promote the Armenian alignment on the side of the Mongols for a Frankish audience, this work, clearly, was for internal consumption, and suggests serious resolution. The image reveals and illuminates the aspirations of the Catholicos at Hiromkla for the Mongol alignment, stressing the hopes invested in the relationship. It demonstrates a - perhaps desperate - optimism that the Mongols will prove to be beneficent patrons, and that the word of God and his servants may be spread though their agency. The Mongol alignment may have been imposed on the Armenians by force of circumstance, but perhaps one should be careful not to underestimate the depth of the emotional commitment made by the Armenian élite to its possibilities, foremost being the conversion of these Tatars themselves. Alongside the Sinai icon, T'oros Rōslin's extraordinary image may, perhaps, allow us an insight into the aspirations and hopes of the Christian communities in the Near East faced with the tumultuous arrival of the Mongol hordes.

\footnotetext{
$\Delta$

${ }^{84}$ Der Nersessian, Miniature Painting, i, p. 60

85 There are many examples of portraits in works from this period from the Armenian kingdom: see the discussion in Der Nersessian, Miniature Painting, i, pp. 154-162. Two near contemporary donor examples from Gospel Books are: the portrait of Queen Keran, King Lewon II and their children in the 'Keran Gospels', produced in Sis in Cilicia in 1272, by a scribe, Avetis, known to have worked on volumes illustrated by $\mathrm{T}^{\text {'oros }}$ Rōslin (Jerusalem, Arm. Patr. 2563, fol. 380; in Der Nersessian, Miniature Painting, fig. 641); or that of Archbishop John, brother of King Het'um I, depicting his ordination of priests, in a Gospel Book possibly produced in Akner in 1289 (Erevan, Matenadaran 197, fol. 341v; see also Der Nersessian, Miniature Painting, i, pp.96-97, and fig. 645).

${ }^{86}$ For example, see the accounts of the betrayal of the Seljuk Sultan's mother and sister after the battle of Köse Dagh that confirmed the initial submission by Het'um I to the Mongols: above, p.1, n.5.
} 
ANGUS STEWART

[CAPTIONS FOR FIGURES]

Fig. 1

T'oros Rōslin, frontispiece to the Gospel of Matthew, Gospel book copied for Catholicos Kostandin I, Hromkla, 1260, Jerusalem, Arm. Patr. 251, fol. 15v. Photograph courtesy of Claude Mutafian.

Fig. 2

Scene of the Nativity and the Adoration of the Three Magi, from the 'Iconostasis Beam of the Twelve Feasts', St Catherine's, Mount Sinai. Published through the courtesy of the Michigan-Princeton-Alexandria Expeditions to Mount Sinai; inventory number 1744 in the Sinai Archive at the University of Michigan. 